\title{
Distribusi Bakteri Penghasil Enzim Ekstraseluler Pada Saluran Pencernaan Lobster Mutiara (Panulirus ornatus)
}

\section{Distribution of Extraselular Enzyme Producing Bacteria in Gastroinstestinal Tract of Pearl Lobster (Panulirus ornatus)}

\author{
Faturrahman*, Ismiati, Arbai Kartika Nurhasanah \\ Program Studi Biologi, Fakultas Matematika dan Ilmu Pengetahuan Alam, \\ Universitas Mataram, \\ Jl. Majapahit 62 Mataram 83125, Telp. (0370) 646506 INDONESIA \\ *corresponding author, email: fatur@unram.ac.id
}

Manuscript received: 10-12-2019. Accepted: 20-12-2019

\begin{abstract}
ABSTRAK
Aktivitas fungsi pencernaan hewan dipengaruhi oleh sekresi enzim-enzim ekstraseluler dari bakteri pada saluran pencernaannya. Penelitian ini bertujuan untuk mengevaluasi distribusi bakteri penghasil enzim protease, amilase dan lipase ekstraseluler dari saluran pencernaan lobster mutiara, Panulirus ornatus. Isolat bakteri yang memiliki aktivitas enzim ekstraseluler didasarkan pada kemampuannya untuk membentuk zona bening pada media uji. Hasil penelitian menunjukkan bahwa dari 51 isolat bakteri dari saluran pencernaan $P$. ornatus, didapatkan bakteri proteolitik sebesar $27.45 \%$, bakteri amilolitik sebesar $23.53 \%$ dan bakteri lipolitk sebesar $21.77 \%$. Berdasarkan dominansi bakteri pada segmen saluran pencernaan, yakni bagian kardiak, pilorik dan usus berturut-turut didominasi oleh bakteri amilolitik sebesar $33.33 \%$, proteolitik sebesar $37.50 \%$ dan lipolitik sebesar $29.41 \%$. Aktivitas bakteri proteolitik, amilolitik dan lipolitik tertinggi berturut-turut dicapai oleh isolat SP5 dengan diameter zona bening $12 \mathrm{~mm}$, isolat SK10 dengan diameter zona bening $21 \mathrm{~mm}$ dan isolat SU15 dengan diameter zona bening $20 \mathrm{~mm}$. Jenis bakteri yang dominan pada segmen saluran pencernaan dipengaruhi oleh fungsi fisiologis segmen saluran pencernaan itu sendiri.
\end{abstract}

Kata kunci: Panulirus ornatus; proteolitik; amilolitik; lipolitik

\footnotetext{
ABSTRACT

The activity of the digestive function of animals is influenced by the secretion of extracellular enzymes from bacteria in the digestive tract. This study aims to evaluate the distribution of bacteria producing protease enzyme, amylase and lipase from the digestive tract of pearl lobster, Panulirus ornatus. Bacterial isolates that have extracellular enzyme activity are based on their ability to form clear zones in the test media. The results showed that of 51 bacterial isolates from the digestive tract of P. ornatus, proteolytic bacteria were $27.45 \%$, amylolytic bacteria were $23.53 \%$ and lipolytic bacteria were $21.77 \%$. Based on bacterial dominance in the gastrointestinal segment, namely the cardiac, piloric and intestinal sections, it was dominated by amylolytic bacteria at $33.33 \%$, proteolytic at $37.50 \%$ and lipolytic at $29.41 \%$. The activity of proteolytic, amylolytic and lipolytic bacteria based on the highest clear zone
} 
diameter was achieved respectively by SP5 isolates of $12 \mathrm{~mm}$, SK10 isolates of $21 \mathrm{~mm}$ and SU15 isolates of $20 \mathrm{~mm}$. The three bacterial isolates were potential as probiotic aquacultur candidates.

Keyword: Panulirus ornatus; proteolytic; amylolytic; lipolytic

\section{PENDAHULUAN}

Lobster mutiara (Panulirus ornatus) merupakan salah satu lobster yang potensial hidup di perairan Indo-Pasifik (Phillips et al., 1980), dan menjadi salah satu spesies akuakultur yang paling menarik untuk dibudidayakan, karena pada pasar global permintaannya terus meningkat dan mencapai harga US\$ 37 per kilogram (Suastika, 2008).

Mikroorganisme yang termakan oleh lobster baik yang berasal dari pakan maupun habitatnya akan membentuk koloni dalam saluran pencernaannya yang disebut mikroflora. Pelczar dan Chan (2005) menyatakan bahwa mikroflora normal saluran pencernaan dengan inangnya memiliki hubungan mutualisme, yakni mikroflora akan memanfaatkan inang sebagai tempat hidupnya dengan memakan sisa atau bahan buangan, sedangkan keuntungan bagi inang adalah mikroba dapat membantu mensintesis vitamin, mensekresi enzim, dan membantu pencernaan nutrien. Mikroflora di dalam saluran pencernaan dapat menghasilkan berbagai jenis enzim dari kelompok enzim protease, lipase dan amilase (Buchet et al. 2000).

Mikroorganisme yang menguntungkan bagi inangnya disebut sebagai bakteri probiotik. Aplikasi probiotik tidak hanya berfungsi sebagai agen biokontrol untuk mengurangi serangan penyakit atau bioremediasi, melainkan dapat pula meningkatkan nilai nutrisi pakan dan laju penyerapan nutrien sehingga memungkinkan udang mencapai pertumbuhan yang maksimum (Widanarni et al., 2012). Menurut Widanarni et al., (2003) bakteri probiotik yang digunakan dalam meningkatkan kelangsungan hidup larva udang windu yang menunjukkan performa terbaik terhadap serangan bakteri patogen Vibrio harveyi adalah bakteri Vibrio alginolyticus. Menurut Tepu (2006), bakteri Pseudoalteromonas piscicida juga dapat menekan bakteri Vibrio harveyi dan telah diuji mampu menghasilkan enzim protease dan amilase yang dapat membantu mencerna pakan.

Seleksi bakteri probiotik khususnya bakteri penghasil enzim ekstraseluler (proteolitik, amilolitik dan lipolitik) dari saluran pencernaan lobster mutiara yang dapat membantu mencerna pakan, sangat perlu untuk dilakukan sebagai salah satu upaya untuk meningkatkan produktivitas lobster mutiara.

\section{Sumber Isolat}

\section{BAHAN DAN METODE}

Sebanyak 51 isolat bakteri yang telah diisolasi dari saluran pencernaan lobster mutiara dengan rincian sebagai berikut: 18 isolat berasal dari segmen kardiak, 16 isolat dari pilorik dan 17 isolat dari segmen usus (Nurhasanah dan Faturrahman, 2019).

\section{Peremajaan Isolat Bakteri}

Terhadap ke-51 isolat bakteri tersebut diremajakan dengan cara mengambil 1 ose isolat dari biakan murni dan diinokulasi pada media media SWC agar dengan metode streak plate secara aseptis. Kemudian diinkubasi selama 24 jam pada suhu $25^{\circ} \mathrm{C}$. 


\section{Pembuatan Media Uji}

Media sea water complex (SWC) agar dibuat sebagai media pertumbuhan dan media uji. Media SWC agar dibuat dengan mencampurkan 6 gr Nutrient Broth, 3 ml gliserol, 15 gr agar dan $250 \mathrm{ml}$ aquades ke dalam erlenmeyer kapasitas $2.000 \mathrm{ml}$, kemudian didespersikan dengan air laut steril hingga mencapai $1.000 \mathrm{ml}$.

\section{Pembuatan Kultur Cair}

Kultur cair dibuat berdasarkan metode Setioningsih et al (2004) yang telah dimodifikasi. Isolat bakteri yang telah diremajakan diinokulasi masing-masing sebanyak 1 ose ke dalam $10 \mathrm{ml}$ media SWC broth, setelah itu digojok menggunakan vortex, kemudian diinkubasi pada pada suhu $25^{\circ} \mathrm{C}$ selama 24 jam.

\section{Seleksi Bakteri Penghasil Enzim Ekstraseluler}

Seleksi bakteri dilakukan berdasarkan kemampuan bakteri untuk menghidrolisis kasein, pati dan lemak yang terdapat dalam media uji. Aktivitas enzim ekstraseluler dilakukan berdasarkan metode difusi agar dengan membuat lubang sumuran pada media uji. Sebanyak $8 \mu 1$ kultur diinokulasikan pada sumuran media uji menggunakan mikropipet. Setelah itu diinkubasi pada suhu $25^{\circ} \mathrm{C}$ selama 24 jam hingga 72 jam, kemudian diamati dan diukur zona bening yang terbentuk. Menurut Olajuyigbe dan Ajele (2008), zona bening yang terbentuk pada substrat mengindikasikan adanya aktivitas enzim oleh bakteri yang tumbuh pada medium tersebut.

\section{Analisis Data}

Distribusi bakteri yang memiliki aktivitas proteolitik, amilolitik, dan lipolitik pada segmen saluaran pencernaan dihitung berdasarkan persentase kehadirannya terhadap total pada segmen tersebut dan terhadap total bakteri pada seluruh segmen saluran pencernaan, yaitu dengan menggunakan persamaan rumus sebagai berikut:

$$
\text { Distribusi Bakteri }=\frac{\text { Jumlah bakteri penghasil enzim }}{\text { Jumlah total bakteri }} \times 100 \%
$$

\section{HASIL DAN PEMBAHASAN}

Isolat bakteri yang digunakan dalam penelitian ini adalah sebanyak 51 isolat yang terdiri atas 18 isolat berasal dari segmen kardiak, 16 isolat dari pilorik dan 17 isolat dari segmen usus. Isolat-isolat tersebuat telah diisolasi dari saluran pencernaan lobster mutiara oleh Nurhasanah dan Faturrahman, (2019). Adapun rincian ke-51 isolat tersebut disajikan dalam Tabel 1.

Tampilan warna koloni ke-51 isolat pada media Sea Water Complex didominasi oleh warna putih (11 isolat), diikuti oleh warna putih susu (9 isolat), kuning (6 isolat), bening (4 isolat), kuning bening ( 4 isolat), putih membentuk zona bening ( 3 isolat), putih kehijauan (4 isolat), putih bening ( 2 isolat), putih kekuningan ( 2 isolat), putih bening ditengah kuning (1 isolat), kuning bening membentuk zona bening ( 1 isolat), bening ditengah kuning ( 1 isolat), dan putih ditengah bening. Adapun bentuk didominasi oleh bulat (26 isolat), kemudian diikuti oleh bentuk tidak beraturan (18 isolat), agak lonjong ( 5 isolat), berserabut ( 1 isolat) dan bulat memanjang ( 1 isolat). Tampilan tepian koloni didominasi oleh tepian tidak rata (23 isolat), 
diikuti oleh tepian rata (20 isolat), bergelombang ( 5 isolat), dan berserabut ( 3 isolat).Pada media Marine Agar didominasi oleh tepian tidak rata (19 isolat) dan tepian rata (5 isolat).

Tabel 1. Data jenis isolat bakteri asal saluran pencernaan lobster mutiara dan karakteristik makro dan mikroskopiknya

\begin{tabular}{|c|c|c|c|c|c|c|c|c|}
\hline \multirow[t]{2}{*}{ No } & \multirow{2}{*}{$\begin{array}{c}\text { Segmen } \\
\text { asal } \\
\text { isolat } \\
\end{array}$} & \multirow{2}{*}{$\begin{array}{l}\text { Kode } \\
\text { isolat }\end{array}$} & \multirow[b]{2}{*}{$\begin{array}{c}\text { Bentuk } \\
\text { koloni }\end{array}$} & \multirow[b]{2}{*}{$\begin{array}{l}\text { Warna } \\
\text { koloni }\end{array}$} & \multirow[b]{2}{*}{$\begin{array}{l}\text { Tepian } \\
\text { koloni }\end{array}$} & \multicolumn{3}{|c|}{ Karakteristik mikroskopik } \\
\hline & & & & & & Bentuk sel & $\begin{array}{c}\text { Pewarnaan } \\
\text { Gram }\end{array}$ & Motilitas \\
\hline 1 & Kardiak & SK1 & Bulat & Kuning & Rata & Diplococcus & Gram positif & Motil \\
\hline 2 & Kardiak & SK2 & Bulat & Putih susu & Rata & Basil panjang & Gram positif & Nonmotil \\
\hline 3 & Kardiak & SK3 & Bulat & $\begin{array}{l}\text { Putih bening } \\
\text { di tengah } \\
\text { kuning }\end{array}$ & Rata & Basil panjang & Gram positif & Motil \\
\hline 4 & Kardiak & SK4 & Bulat & Bening & Rata & Monococcus & Gram positif & Motil \\
\hline 5 & Kardiak & SK5 & Bulat & Putih & $\begin{array}{c}\text { Bergelomba } \\
\text { ng }\end{array}$ & Streptococcus & Gram negatif & Motil \\
\hline 6 & Kardiak & SK6 & $\begin{array}{c}\text { Tidak } \\
\text { beraturan }\end{array}$ & Putih susu & Tidak rata & Monococcus & Gram negatif & Motil \\
\hline 7 & Kardiak & SK7 & Bulat & Putih & $\begin{array}{c}\text { Bergelomba } \\
\text { ng }\end{array}$ & Monococcus & Gram positif & Motil \\
\hline 8 & Kardiak & SK8 & Bulat & $\begin{array}{l}\text { Putih } \\
\text { membentuk } \\
\text { zona bening }\end{array}$ & Rata & Monococcus & Gram positif & Nonmotil \\
\hline 9 & Kardiak & SK9 & $\begin{array}{c}\text { Tidak } \\
\text { beraturan }\end{array}$ & Putih susu & Berserabut & Diplococcus & Gram positif & Motil \\
\hline 10 & Kardiak & SK10 & $\begin{array}{c}\text { Agak } \\
\text { lonjong }\end{array}$ & Putih & Tidak rata & Diplococcus & Gram positif & Motil \\
\hline 11 & Kardiak & SK11 & $\begin{array}{c}\text { Tidak } \\
\text { beraturan }\end{array}$ & $\begin{array}{l}\text { Putih } \\
\text { membentuk } \\
\text { zona bening }\end{array}$ & Tidak rata & Diplococcus & Gram positif & Motil \\
\hline 12 & Kardiak & SK12 & Bulat & Bening & Berserabut & Monococcus & Gram positif & Motil \\
\hline 13 & Kardiak & SK13 & Berserabut & Bening & Tidak rata & Monococcus & Gram positif & Motil \\
\hline 14 & Kardiak & SK14 & $\begin{array}{c}\text { Tidak } \\
\text { beraturan }\end{array}$ & $\begin{array}{c}\text { Putih } \\
\text { kehijauan }\end{array}$ & Tidak rata & Diplococcus & Gram positif & Nonmotil \\
\hline 15 & Kardiak & SK15 & $\begin{array}{c}\text { Tidak } \\
\text { beraturan }\end{array}$ & $\begin{array}{c}\text { Putih } \\
\text { kehijauan }\end{array}$ & Tidak rata & Streptococcus & Gram negatif & Motil \\
\hline 16 & Kardiak & SK16 & $\begin{array}{c}\text { Tidak } \\
\text { beraturan }\end{array}$ & $\begin{array}{c}\text { Putih } \\
\text { kehijauan }\end{array}$ & $\begin{array}{c}\text { Bergelomba } \\
\text { ng }\end{array}$ & Streptococcus & Gram positif & Motil \\
\hline 17 & Kardiak & SK17 & Bulat & $\begin{array}{c}\text { Putih } \\
\text { kehijauan }\end{array}$ & Rata & Monococcus & Gram positif & Motil \\
\hline 18 & Kardiak & SK18 & Bulat & $\begin{array}{l}\text { Kuning } \\
\text { bening }\end{array}$ & $\begin{array}{c}\text { bergelomba } \\
\text { ng }\end{array}$ & Streptococcus & Gram positif & Motil \\
\hline 19 & Pilorik & SP1 & $\begin{array}{c}\text { Tidak } \\
\text { beraturan }\end{array}$ & $\begin{array}{c}\text { Putih } \\
\text { kekuningan }\end{array}$ & Rata & Monococcus & Gram negatif & Motil \\
\hline 20 & Pilorik & SP2 & $\begin{array}{c}\text { Tidak } \\
\text { beraturan }\end{array}$ & Kuning & Tidak rata & Diplococcus & Gram negatif & Motil \\
\hline 21 & Pilorik & SP3 & $\begin{array}{c}\text { Agak } \\
\text { lonjong }\end{array}$ & Putih & Tidak rata & Monococcus & Gram negatif & Motil \\
\hline 22 & Pilorik & SP4 & Bulat & Putih susu & Rata & Diplococcus & Gram negatif & Motil \\
\hline 23 & Pilorik & SP5 & $\begin{array}{c}\text { Tidak } \\
\text { beraturan }\end{array}$ & Putih susu & Tidak rata & Diplococcus & Gram negatif & Motil \\
\hline 24 & Pilorik & SP6 & $\begin{array}{c}\text { Tidak } \\
\text { beraturan }\end{array}$ & Putih susu & Berserabut & Monococcus & Gram positif & Nonmotil \\
\hline 25 & Pilorik & SP7 & Bulat & $\begin{array}{c}\text { Kuning } \\
\text { bening } \\
\text { membentuk } \\
\text { zona bening }\end{array}$ & Rata & Streptococcus & Gram negatif & Motil \\
\hline 26 & Pilorik & SP8 & Bulat & $\begin{array}{l}\text { Putih } \\
\text { membentuk } \\
\text { zona bening }\end{array}$ & Rata & Monococcus & Gram negatif & Motil \\
\hline
\end{tabular}


Tabel 1. Data jenis isolat bakteri asal saluran pencernaan lobster mutiara dan karakteristik makro dan mikroskopiknya (lanjutan)

\begin{tabular}{|c|c|c|c|c|c|c|c|c|}
\hline \multirow[t]{2}{*}{ No } & \multirow{2}{*}{$\begin{array}{c}\text { Segmen } \\
\text { asal } \\
\text { isolat }\end{array}$} & \multirow{2}{*}{$\begin{array}{l}\text { Kode } \\
\text { isolat }\end{array}$} & \multirow[b]{2}{*}{$\begin{array}{c}\text { Bentuk } \\
\text { koloni }\end{array}$} & \multirow[b]{2}{*}{$\begin{array}{l}\text { Warna } \\
\text { koloni }\end{array}$} & \multirow[b]{2}{*}{$\begin{array}{l}\text { Tepian } \\
\text { koloni }\end{array}$} & \multicolumn{3}{|c|}{ Karakteristik mikroskopik } \\
\hline & & & & & & Bentuk sel & $\begin{array}{c}\text { Pewarnaan } \\
\text { Gram }\end{array}$ & Motilitas \\
\hline 27 & Pilorik & SP9 & $\begin{array}{c}\text { Tidak } \\
\text { beraturan }\end{array}$ & Kuning & $\begin{array}{c}\text { Ber- } \\
\text { gelombang }\end{array}$ & Diplococcus & Gram positif & Motil \\
\hline 28 & Pilorik & SP10 & Bulat & $\begin{array}{c}\text { Bening di } \\
\text { tengah } \\
\text { kuning }\end{array}$ & Rata & Monococcus & Gram negatif & Nonmotil \\
\hline 29 & Pilorik & SP11 & Bulat & Putih bening & Rata & Streptococcus & Gram positif & Motil \\
\hline 30 & Pilorik & SP12 & $\begin{array}{c}\text { Tidak } \\
\text { beraturan }\end{array}$ & Putih & Tidak rata & Monococcus & Gram positif & Motil \\
\hline 31 & Pilorik & SP13 & $\begin{array}{l}\text { Agak } \\
\text { lonjong }\end{array}$ & Putih & Tidak rata & Streptococcus & Gram positif & Motil \\
\hline 32 & Pilorik & SP14 & $\begin{array}{l}\text { Tidak } \\
\text { beraturan }\end{array}$ & Bening & Tidak rata & Streptococcus & Gram positif & Motil \\
\hline 33 & Pilorik & SP15 & Bulat & Kuning & Rata & Streptococcus & Gram positif & Motil \\
\hline 34 & Pilorik & SP16 & $\begin{array}{c}\text { Tidak } \\
\text { beraturan }\end{array}$ & Kuning & Tidak rata & Streptococcus & Gram positif & Motil \\
\hline 35 & Usus & SU1 & $\begin{array}{c}\text { Tidak } \\
\text { beraturan }\end{array}$ & Putih & Tidak rata & Monococcus & Gram positif & Motil \\
\hline 36 & Usus & SU2 & Bulat & Putih & Rata & Staphylococcus & Gram positif & Motil \\
\hline 37 & Usus & SU3 & $\begin{array}{c}\text { Agak } \\
\text { lonjong }\end{array}$ & Putih susu & Rata & Monococcus & Gram positif & Motil \\
\hline 38 & Usus & SU4 & Bulat & Putih susu & Rata & Diplococcus & Gram positif & Motil \\
\hline 39 & Usus & SU5 & $\begin{array}{c}\text { Bulat } \\
\text { memanjang }\end{array}$ & Putih & Tidak rata & Streptococcus & Gram negatif & Motil \\
\hline 40 & Usus & SU6 & Bulat & $\begin{array}{c}\text { Putih } \\
\text { kekuningan }\end{array}$ & Rata & Diplococcus & Gram negatif & Motil \\
\hline 41 & Usus & SU7 & $\begin{array}{c}\text { Agak } \\
\text { lonjong }\end{array}$ & Kuning & Tidak rata & Streptococcus & Gram positif & Motil \\
\hline 42 & Usus & SU8 & $\begin{array}{c}\text { Tidak } \\
\text { beraturan }\end{array}$ & Putih susu & Tidak rata & Diplococcus & Gram negatif & Motil \\
\hline 43 & Usus & SU9 & Bulat & $\begin{array}{c}\text { Putih di } \\
\text { tengah } \\
\text { bening }\end{array}$ & Tidak rata & Diplococcus & Gram negatif & Motil \\
\hline 44 & Usus & SU10 & Bulat & Putih & Rata & Monococcus & Gram positif & Nonmotil \\
\hline 45 & Usus & SU11 & $\begin{array}{c}\text { Tidak } \\
\text { beraturan }\end{array}$ & Putih & Tidak rata & Monococcus & Gram positif & Nonmotil \\
\hline 46 & Usus & SU12 & Bulat & $\begin{array}{l}\text { Kuning } \\
\text { bening }\end{array}$ & Rata & Streptococcus & Gram negatif & Motil \\
\hline 47 & Usus & SU13 & Bulat & Putih bening & Rata & Monococcus & Gram negatif & Motil \\
\hline 48 & Usus & SU14 & Bulat & Putih & Tidak rata & Diplococcus & Gram negatif & Motil \\
\hline 49 & Usus & SU15 & Bulat & Putih & Tidak rata & Streptococcus & Gram positif & Motil \\
\hline 50 & Usus & SU16 & Bulat & $\begin{array}{l}\text { Kuning } \\
\text { bening }\end{array}$ & Tidak rata & Streptococcus & Gram positif & Motil \\
\hline 51 & Usus & SU17 & $\begin{array}{c}\text { Tidak } \\
\text { beraturan }\end{array}$ & $\begin{array}{l}\text { Kuning } \\
\text { bening }\end{array}$ & Tidak rata & Monococcus & Gram negatif & Nonmotil \\
\hline
\end{tabular}

Berdasarkan tampilan morfologi koloni (bentuk, warna dan tepian koloni) dan sel (bentuk dan penataan sel, reaksi gram dan motilitas) menunjukkan bahwa ke lima puluh satu isolat bakteri tersebut beragam dan diduga sebagai spesies yang berbeda-beda. Selanjutnya terhadap ke-51 isolat tersebut diuji kemampuannya dalam menghidrolisis pati, protein dan lemak. 
Berdasarkan hasil uji aktivitas enzim, dari 51 isolat bakteri yang diseleksi pada media SWC, didapatkan 14 isolat bakteri yang memiliki aktivitas proteolitik, masingmasing didapatkan pada bagian kardiak 7 isolat, pilorik 6 isolat dan usus 4 isolat. Bakteri yang memiliki aktivitas amilolitik didapatkan sebanyak 12 isolat, masing-masing didapatkan pada bagian kardiak 8 isolat, pilorik 3 isolat dan usus 3 isolat. Bakteri yang memiliki aktivitas lipolitik didapatkan sebanyak 11 isolat, masing-masing didapatkan pada bagian kardiak 2 isolat, pilorik 4 isolat dan usus 5 isolat (Tabel 2).

Tabel 2. Hasil Uji Hidrolisis Kasein, Pati dan Lemak secara kualitatif oleh Bakteri Saluran Pencernaan Lobster Mutiara pada Media SWC Agar

\begin{tabular}{|c|c|c|c|c|c|}
\hline \multirow[t]{2}{*}{ No } & \multirow{2}{*}{$\begin{array}{c}\text { Segmen } \\
\text { asal isolat }\end{array}$} & \multirow[t]{2}{*}{ Kode isolat } & \multicolumn{3}{|c|}{ Jenis uji } \\
\hline & & & $\begin{array}{c}\text { Hidrolisis } \\
\text { kasein }\end{array}$ & Hidrolisis pati & $\begin{array}{c}\text { Hidrolisis } \\
\text { lemak }\end{array}$ \\
\hline 1 & Kardiak & SK1 & - & - & - \\
\hline 2 & Kardiak & SK2 & - & - & - \\
\hline 3 & Kardiak & SK3 & - & - & - \\
\hline 4 & Kardiak & SK4 & - & - & - \\
\hline 5 & Kardiak & SK5 & - & - & + \\
\hline 6 & Kardiak & SK6 & - & - & - \\
\hline 7 & Kardiak & SK7 & - & - & - \\
\hline 8 & Kardiak & SK8 & + & - & - \\
\hline 9 & Kardiak & SK9 & + & + & + \\
\hline 10 & Kardiak & SK10 & + & + & - \\
\hline 11 & Kardiak & SK11 & + & - & - \\
\hline 12 & Kardiak & SK12 & - & - & - \\
\hline 13 & Kardiak & SK13 & + & + & - \\
\hline 14 & Kardiak & SK14 & - & + & - \\
\hline 15 & Kardiak & SK15 & - & + & - \\
\hline 16 & Kardiak & SK16 & - & + & - \\
\hline 17 & Kardiak & SK17 & - & - & - \\
\hline 18 & Kardiak & SK18 & - & - & - \\
\hline 19 & Pilorik & SP1 & - & - & + \\
\hline 20 & Pilorik & SP2 & + & - & - \\
\hline 21 & Pilorik & SP3 & + & - & - \\
\hline 22 & Pilorik & SP4 & + & - & - \\
\hline 23 & Pilorik & SP5 & + & - & - \\
\hline 24 & Pilorik & SP6 & + & - & - \\
\hline 25 & Pilorik & SP7 & - & - & + \\
\hline 26 & Pilorik & SP8 & - & - & + \\
\hline 27 & Pilorik & SP9 & - & - & + \\
\hline 28 & Pilorik & SP10 & - & - & - \\
\hline 29 & Pilorik & SP11 & - & + & - \\
\hline 30 & Pilorik & SP12 & + & - & - \\
\hline 31 & Pilorik & SP13 & - & + & - \\
\hline 32 & Pilorik & SP14 & - & + & - \\
\hline 33 & Pilorik & SP15 & - & - & - \\
\hline 34 & Pilorik & SP16 & - & - & - \\
\hline 35 & Usus & SU1 & - & - & - \\
\hline 36 & Usus & SU2 & - & - & - \\
\hline 37 & Usus & SU3 & - & - & - \\
\hline 38 & Usus & SU4 & - & - & + \\
\hline 39 & Usus & SU5 & - & - & - \\
\hline
\end{tabular}


Tabel 2. Hasil Uji Hidrolisis Kasein, Pati dan Lemak secara kualitatif oleh Bakteri Saluran Pencernaan Lobster Mutiara pada Media SWC Agar (lanjutan)

\begin{tabular}{lllccc}
\hline No & $\begin{array}{c}\text { Segmen } \\
\text { asal isolat }\end{array}$ & Kode isolat & \multicolumn{3}{c}{ Jenis uji } \\
\cline { 4 - 6 } & & & $\begin{array}{c}\text { Hidrolisis } \\
\text { kasein }\end{array}$ & $\begin{array}{c}\text { Hidrolisis } \\
\text { pati }\end{array}$ & $\begin{array}{c}\text { Hidrolisis } \\
\text { lemak }\end{array}$ \\
\hline 40 & Usus & SU6 & - & - & - \\
41 & Usus & SU7 & - & - & - \\
42 & Usus & SU8 & - & - & - \\
43 & Usus & SU9 & - & - & - \\
44 & Usus & SU10 & - & - & - \\
45 & Usus & SU11 & - & + & - \\
46 & Usus & SU12 & - & - & - \\
47 & Usus & SU13 & + & + & - \\
48 & Usus & SU14 & - & - & + \\
49 & Usus & SU15 & + & - & + \\
50 & Usus & SU16 & - & - & + \\
51 & Usus & SU17 & + & + & + \\
\hline
\end{tabular}

Berdasarkan kemampuan multiaktivitas, didapatkan 2 isolat bakteri yang memiliki aktivitas proteolitik, amlolitik dan lipolitik yakni isolat SK9 dan isolat SU17. Jumlah total bakteri yang memiliki aktivitas proteolitik dan amilolitik adalah 3 isolat, yakni SK10, SK13 dan SU13. Jumlah total bakteri yang memiliki aktivitas proteolitik dan lipolitik adalah 1 isolat, yakni SU15, dan tidak ditemukan isolat bakteri yang memiliki aktivitas amilolitik dan lipolitik sekaligus.

Metode pengujian bakteri dilakukan dengan pengamatan zona bening yang terbentuk. Menurut Hou dan Johnston (1992), asam amino yang dihasilkan dari proses penguraian protein oleh bakteri larut dalam media, sehingga kekeruhan media akan hilang dan terbentuklah zona bening, sehingga mengindikasikan bakteri menghidrolisis senyawa protein. Menurut Ward et al., (2003) dalam Philips (2006), makanan yang baik untuk lobster adalah pakan yang mengandung konsentrasi protein sebesar 24-50\%. Dengan demikian, bakteri proteolitik lebih banyak dibutuhkan untuk membantu menghidrolisis senyawa protein tersebut.

Potensi bakteri amilolitik diukur berdasarkan kemampuan isolat bakteri dalam mensekresikan enzim amilase. Metode pengujian enzim amilase ditentukan berdasarkan zona bening yang terbentuk pada medium yang telah diperkaya starch atau pati dan larutan lugol iodin. Isolat bakteri memiliki aktivitas enzim amilase ekstraseluler dapat menghidrolisis pati (amilosa dan amilopektin). Pati yang telah terhidrolisis tidak dapat berikatan dengan lugol iodin, sehingga terbentuk zona bening (Zahidah dan Shovitri, 2013). Karbohidrat menjadi komponen dasar organisme hidup, karena merupakan sumber utama dalam pembentukan energi (Phillips, 2006). Menurut Kakam et al., lobster membutuhkan kandungan karbohidrat dalam pakannya sebesar $29.4 \%$.

Lemak merupakan nutrisi yang digunakan sebagai bahan pembentuk asam lemak esensial dan sumber energi (Yuwono, 2005). Crustasea memiliki kemampuan yang terbatas untuk mensintesis fosfolipid (Phillips, 2006), sehingga bakteri lipolitik sangat diperlukan untuk membantu mencukupi kebutuhannya. Potensi bakteri lipolitik ditandai dengan 
terbentuknya zona bening pada medium yang telah diperkaya senyawa lipid. Senyawa lemak merupakan ikatan 3 buah gliserol atau trigliserida. Jika trigliserida tersebut terhidrolisis baik oleh enzim maupun pelarut tertentu, maka akan terbentuk gliserol dan tiga buah asam lemak yang ekuivalen (Lehninger, 1991).

Menurut Kakam et al (2008), crustacea membutuhkan 7\% lemak dalam pakannya agar memiliki tingkat pertumbuhan yang baik. Lipid yang dihidrolisis menjadi asam lemak dan gliserol oleh bakteri lipolitik akan digunakan sebagai surnber karbon dan energi untuk metabolismenya (Hou dan Johnston 1992).

Kardiak dan pilorik merupakan bagian atas dan bawah lambung. Lambung pada organisme hidup dapat mensekresikan beberapa enzim, diantaranya adalah enzim pepsin yang dapat menguraikan protein menjadi polipeptida dan pepton. Selain itu, lambung juga dapat menguraikan karbohidrat menjadi amilum dan lemak menjadi asam lemak dan gliserol dengan bantuan enzim amilase dan lipase. Setelah melewati lambung, makanan akan masuk ke dalam usus yang juga berfungsi menghasilkan enzim pencernaan, yakni enzim lipase, peptidase dan laktase. Keberadaan bakteri pada saluran pencernaan dapat membantu meningkatkan laju pertumbuhan dan aktivitas enzim pencernaan (Faturrahman et al., 2015).

Tabel 3. Distribusi Bakteri Penghasil Enzim Pencernaan pada segmen saluaran pencernaan lobster mutiara

\begin{tabular}{lrrr}
\hline Segmen Saluran & \multicolumn{3}{c}{ Keragaman Bakteri Penghasil Enzim Pencernaan (\%) } \\
\cline { 2 - 4 } Pencernaan & Proteolitik & Amilolitik & Lipolitik \\
\hline Kardiak & 25.93 & 29.63 & 7.41 \\
Pilorik & 26.08 & 13.04 & 17.39 \\
Usus & 16.00 & 12.00 & 20.00 \\
\hline Distribusi total & 22.67 & 18.67 & 14.67 \\
\hline
\end{tabular}

Berdasarkan hasil penelitian, pada bagian kardiak lobster mutiara didominasi oleh bakteri amilolitik yakni $29.63 \%$, kemudian bakteri proteolitik sebesar $25.93 \%$, dan bakteri lipolitik sebesar $7.41 \%$, sehingga dapat diasumsikan bahwa bagian kardiak lobster mutiara lebih banyak menghidrolisis karbohidrat dan protein serta mencerna karbohidrat terlebih dahulu untuk memenuhi kebutuhan energinya. Bagian pilorik didominasi oleh bakteri proteolitik yakni $26.08 \%$, sedangkan bakteri amilolitik dan lipolitik tidak jauh berbeda, yakni $13.04 \%$ dan $17.39 \%$. Usus pada lobster mutiara, lebih banyak menghidrolisis lipid karena bagian ini didominasi oleh bakteri lipolitik, yakni $20.00 \%$, kemudian bakteri proteolitik sebesar $16.00 \%$ dan bakteri amilolitik sebesar $12.00 \%$ (Tabel 3). Menurut Isnaeni (2006), lipid akan mulai dicerna setelah pakan sampai pada usus.

Persentase total keragaman bakteri tertinggi hingga terendah berturut-turut adalah bakteri proteolitik yakni sebesar $22.67 \%$, kemudian bakteri amilolitik sebesar $18.67 \%$, dan bakteri lipolitik sebesar 14.67\% (Tabel 3). Data tersebut menunjukkan bahwa, pada saluran pencernaan lobster mutiara didominasi oleh bakteri proteolitik. Hal ini diduga berkaitan dengan kebiasaan makan crustacea yang tergolong hewan karnivora, dimana kandungan protein dalam pakannya yang optimum bagi pertumbuhannya sebesar $40 \%$ (Benedict et al., 2002). Telah diketahui juga bahwa kandungan pakan alami crustacea berupa cacing lur 
mengandung protein sebesar 56\% (Rachmad dan Yuwono, 2000). Pakan alami maupun pakan buatan yang diberikan pada lobster harus sesuai dengan kemampuan mencerna lobster itu sendiri, sehingga kandungan dalam pakan tersebut dapat dicerna dengan baik.

Tabel 4. Diameter Zona Bening dari Isolat Bakteri yang memiliki aktivitas enzim ekstraseluler dari Saluran Pencernaan Lobster Mutiara

\begin{tabular}{|c|c|c|c|c|c|}
\hline \multirow[t]{2}{*}{ No } & \multirow[t]{2}{*}{ Kode isolat } & \multirow[t]{2}{*}{ Jenis isolate } & \multicolumn{3}{|c|}{ Diameter zona bening $(\mathrm{mm})$} \\
\hline & & & Hidrolisis kasein & Hidrolisis pati & Hidrolisis lemak \\
\hline \multicolumn{6}{|c|}{ Kardiak } \\
\hline 1 & SK5 & Streptococcus & - & - & 13 \\
\hline 2 & SK8 & Monococcus & 9 & - & - \\
\hline 3 & SK9 & Diplococcus & 9 & 19 & 15 \\
\hline 4 & SK10 & Diplococcus & 10 & 21 & - \\
\hline 5 & SK11 & Diplococcus & 10 & - & - \\
\hline 6 & SK13 & Monococcus & 11 & 12 & - \\
\hline 7 & SK14 & Diplococcus & - & 12 & - \\
\hline 8 & SK15 & Streptococcus & - & 14 & - \\
\hline 9 & SK16 & Streptococcus & - & 11 & - \\
\hline \multicolumn{6}{|c|}{ Pilorik } \\
\hline 10 & SP1 & Monococcus & - & - & 14 \\
\hline 11 & SP2 & Diplococcus & 10 & - & - \\
\hline 12 & SP3 & Monococcus & 10 & - & - \\
\hline 13 & SP4 & Diplococcus & 11 & - & - \\
\hline 14 & SP5 & Diplococcus & 12 & - & - \\
\hline 15 & SP6 & Monococcus & 11 & - & - \\
\hline 16 & SP7 & Streptococcus & - & - & 15 \\
\hline 17 & SP8 & Monococcus & - & - & 16 \\
\hline 18 & SP9 & Diplococcus & - & - & 14 \\
\hline 19 & SP11 & Streptococcus & - & 12 & - \\
\hline 20 & SP12 & Monococcus & 10 & - & - \\
\hline 21 & SP13 & Streptococcus & - & 12 & - \\
\hline 22 & SP14 & Streptococcus & - & 11 & - \\
\hline \multicolumn{6}{|c|}{ Usus } \\
\hline 23 & SU4 & Diplococcus & - & - & 10 \\
\hline 24 & SU11 & Monococcus & - & 11 & - \\
\hline 25 & SU13 & Monococcus & 9 & 13 & - \\
\hline 26 & SU14 & Diplococcus & - & - & 16 \\
\hline 27 & SU15 & Streptococcus & 11 & - & 20 \\
\hline 28 & SU16 & Streptococcus & - & - & 19 \\
\hline 29 & SU17 & Monococcus & 10 & 17 & 18 \\
\hline
\end{tabular}

Diameter zona bening isolat bakteri yang memiliki aktivitas enzim ekstraseluler ditunjukkan pada Tabel 4. Bakteri yang memiliki aktivitas proteolitik dari saluran pencernaan lobster mutiara didapatkan sebanyak 17 isolat, dengan diameter zona bening paling tinggi didapatkan pada isolat SP5 yakni $12 \mathrm{~mm}$, sehingga dapat diindikasikan bahwa untuk memecah molekul protein, isolat SP5 berpotensi untuk dijadikan sebagai kandidat bakteri probiotik. Bakteri yang memiliki aktivitas amilolitik didapatkan sebanyak 14 isolat, dengan diameter zona bening paling tinggi terdapat pada isolat SK10 yakni 21 
$\mathrm{mm}$, dengan demikian isolat SK10 dapat berpotensi menjadi kandidat bakteri probiotik untuk memecah molekul pati. Bakteri yang memiliki diameter zona bening paling tinggi berdasarkan aktivitas lipolitik dari 11 isolat yang didapatkan adalah isolat SU15 yakni $20 \mathrm{~mm}$, sehingga isolat SU15 dapat berpotensi menjadi kandidat bakteri probiotik untuk memecah molekul lipid.

Menurut Rahman dan Indarto (2013), semakin luas zona bening yang terbentuk, akan mengindikasikan semakin tinggi kemampuan mikroorganisme dalam menghidrolisis substrat. Selain itu, berdasarkan penelitian Rahma dan Kuswytasari (2013), menyatakan bahwa semakin besar zona bening, maka dapat diindikasikan semakin banyak pula enzim yang disekresikan, sehingga dapat diketahui urutan potensi isolat yang diuji. Begitu juga dengan Putri et al (2013), menyatakan bahwa semakin luas zona bening yang terbentuk mengindikasikan semakin tinggi kemampuan mikroorganisme memecah substratnya yang berarti semakin tinggi kemampuan mikroorganisme tersebut dalam memproduksi enzim ekstraseluler.

Bakteri probiotik akan lebih efektif digunakan apabila probiotik berasal dari jenis mikroorganisme indigenous atau mikroba asli, yaitu langsung diperoleh dari saluran pencernaan dan lingkungan yang sama atau mirip dengan hewan inang (Yulvizar, 2014). Bakteri probiotik secara aktif memproduksi dan mensekresikan enzim-enzim pencernaan yang berperan untuk menguraikan atau menghidrolisis senyawa kompleks menjadi senyawasenyawa sederhana yang dapat masuk ke dalam sel (Subagiya dan Djunaedi, 2011).

Isolat bakteri yang memiliki tigkat aktivitas enzim paling tinggi dapat diindikasikan sebagai kandidat bakteri probiotik yang dapat dimanfaatkan untuk mempermudah daya cerna lobster mutiara, sehingga tingkat pertumbuhan lobster mutiara lebih cepat. Menurut Subagiya dan Djunaedi (2011), secara tidak langsung keberadaan bakteri probiotik dalam saluran pencernaan bermanfaat dalam meningkatkan absorbsi pakan.

Bakteri probiotik dapat diaplikasikan dalam pakan yang diberikan pada lobster mutiara, dengan menambah konsorsium pakan berupa kandidat isolat bakteri probiotik. Keberadaan bakteri probiotik ini akan membantu tingkat pertumbuhan lobster mutiara dan secara tidak langsung dapat dijadikan sebagai salah satu alternatif dalam budidaya lobster mutiara.

\section{KESIMPULAN}

Isolat bakteri saluran pencernaan lobster mutiara terdiri atas bakteri proteolitik sebesar $22.67 \%$, bakteri amilolitik sebesar $18.67 \%$ dan bakteri lipolitk sebesar $14.67 \%$, dengan demikian bakteri yang memiliki aktivitas enzim ekstraseluler pada saluran pencernaan lobster mutiara didominasi oleh bakteri proteolitik. Berdasarkan segmen saluran pencernaan, yakni bagian kardiak, pilorik dan usus berturut-turut didominasi oleh bakteri amilolitik yaitu sebesar $29.63 \%$, bakteri proteolitik sebesar $26.08 \%$, dan lipolitik sebesar $20.00 \%$. Isolat bakteri yang memiliki aktivitas proteolitik, amilolitik dan lipolitik tertinggi berturut-turut didapatkan pada isolat SP5 dengan diameter zona bening $12 \mathrm{~mm}$, isolat SK10 dengan diameter zona bening $21 \mathrm{~mm}$ dan isolat SU15 dengan diameter zona bening $20 \mathrm{~mm}$, sehingga isolat bakteri tersebut diduga dapat dijadikan sebagai kandidat bakteri probiotik. 


\section{Saran}

Perlu dilakukan penelitian uji aktivitas enzim lebih lanjut dan lebih lengkap untuk membuktikan isolat bakteri yang diduga sebagai bakteri kandidat probiotik.

\section{DAFTAR PUSTAKA}

Benedict C. P., S.C. Walters, and R.D. Long. 2002. Effects of Using Different Protein Levels on Freshwater Prawn Macrobrachium Rosenbergii Pond Production. Journal of World Aquaculture, 33(4), 41-43.

Buchet, V., J.L. Zambonino, and C. Cahu. 2000. Development and Response to a Diet Change of Some Digestive Enzymes in Sea Bass (Dicentrachus labrax) Larvae. Journal of Fish Physiology and Biochemistry, 12(5), 399-408.

Faturrahman. M. Anja, M.J. Zairin, dan R. Iman. 2015. The Role of Agarolytic Bacteria in Enhancing Physiological Function for Digestive System of Abalone (Haliotis asinina). Journal of Applied Environmental and Biological Sciences, 5(5), 49-56.

Hou, C.T., and T.M. Johnston. 1992. Screening of Lipase Activities With Culture from The Agricultural Research Culture Collection. Journal of Am. Oil. Chem. Soc, 69, 10881097.

Isnaeni, W. 2006. Fisiologi Hewan, Kanisus, Yogyakarta.

Kakam, Y., S.Laksmi, A. Anam. 2008. Pemberian Pakan yang Berbeda terhadap Pertumbuhan dan Rasio Konversi Pakan Lobster Air Tawar (Cherax quadricarinatus) dengan Sistem Botol [jurnal berkala ilmiah perikanan]. Program Studi Budidaya Perairan. Universitas Airlangga. Surabaya. Vol 3 No 1: 41-47 hlm.

Lehninger, A. L. 1991. Dasar-Dasar Biokimia, Erlangga, Jakarta.

Nurhasanah A.K dan Faturrahman, 2019. Komunitas bakteri pada saluran pencernaan lobster mutiara (Panulirus ornatus). Jurnal Sains Teknologi dan Lingkungan, 5 (1), 1-9

Olajuyigbe, F., M. and J.O. Ajele. 2008. Some Properties of Extracellular Protease from Bacillus licheniformis Lbbl-11 Isolated from "iru", A Traditionally Fermente African Locust Bean Condiment. Journal of Biotechnology \& Biochemistry, 3(1), 42-46.

Pelczar, M.J., dan E.C.S. Chan. 2005. Dasar-Dasar Mikrobiologi, UI Press, Jakarta.

Phillips, B.F. 2006. Lobsters: Biology, Management, Aquaculture and Fisheries. Department of Environmental Biology, Muresk Institute, Curtin University of Technology, Blackwell Publishing, Australia.

Phillips, B.F., J.S. Cobb, and R.W. George. 1980. General Biology. In The Biologi and Management of Lobster, Academic Press, New York.

Putri, A., P. Nurmiati. dan A. Agustien. 2013. Uji Aktivitas Antibakteri Ekstrak Kental Tanaman Pisang Kepok Kuning (Musa paradisiaca Linn.) terhadap Staphylococcus aureus dan Escherichia coli. Jurnal Biologi Universitas Andalas, 2(3), 207-213.

Rahma, T., N. dan N. D. Kuswytasari. 2013. Studi Potensi Isolat Kapang Wonorejo Surabaya dalam Mendegradasi Polimer Bioplastik Poly Hydroxy Butyrate (PHB). Jurnal Sains dan Seni Pomits, 2(2), 55-58. 
Rachmad B., dan E. Yuwono. 2000. Pertumbuhan dan Laju Makan serta Efisiensi Protein pada Post Larva Udang Windu yang Diberi Pakan Mengandung Tepung Cacing Lur. Makalah Seminar Nasional Biologi XVI, ITB. Bandung

Rahman, A. dan C. Indarto. 2013. Aktivitas Proteolitik Mikroorganisme Limbah Padat Pengolahan Tahu, Seminar Nasional Menggagas Kebangkitan Komoditas Unggulan Lokal Pertanian dan Kelautan, Universitas Trunojoyo Madura.

Setioningsih, E. R. Setyaningsih. A. Susilowati. 2004. Pembuatan Minuman Probiotik dari Susu Kedelai dengan Inokulum Lactobacillus casei, Lactobacillus plantarum, dan Lactobacillus acidophilus. Jurnal Bioteknologi. 1(1), 1-6.

Suastika, M. 2008. Studi Kelayakan: Meningkatkan Pembesaran dan Nutrisi Lobster di Nusa Tenggara Barat, Prosiding ACIAR, NTB.

Subagiya dan A. Djunaedi. 2011. Skrining Kandidat Bakteri Probiotik dari Saluran Pencernaan Ikan Kerapu Berdasarkan Aktivitas Antibakteri dan Produksi Enzim Proteolitik Ekstraseluler, Jurnal Ilmu Kelautan, 1(16), 41-48.

Tepu, I. 2006. Seleksi Bakteri Probiotik untuk Biokontrol Vibriosis pada Larva Udang Windu, Penaeus monodon Menggunakan Cara Kultur Bersama, Skripsi, Instiut Pertanian Bogor.

Widanarni, A. Suwanto, Sukenda, and B.W. Lay. 2003. Potency of Vibrio Isolates for Biocontrol of Vibriosis in Tiger Shrimp Penaeus monodon Larvae. Journal Biotropia, 20, 11-23.

Widanarni, D. Wahjuningrum, dan F. Puspita. 2012. Aplikasi Bakteri Probiotik Melalui Pakan Buatan untuk Meningkatkan Kinerja Pertumbuhan Udang Windu Penaeus monodon. Jurnal Sains Terapan, 2(1), 32-49.

Yulvizar, C., D. Irma, dan N.D. Cut. 2014. Seleksi Bakteri Berpotensi Probiotik dari Ikan Mas (Cyprinus carpio) Indegenous Jantho Berdasarkan Aktivitas Antibakteri Secara In Vitro. Jurnal Teknologi dan Industri Pertanian Indonesia, 2(6), 20-24.

Yuwono, E. 2005. Kebutuhan Nutrisi Crustacea dan Potensi Cacing Lur (Nereis polychaeta) untuk Pakan Udang. Jurnal Pembangunan Pedesaan, 1(5), 42-49.

Zahidah, D., dan M. Shovitri. 2013. Isolasi, Karakterisasi dan Potensi Bakteri Aerob sebagai Pendegradasi Limbah Organik. Jurnal Sains dan Seni Pomits, 1(2), 2337-3520. 